\title{
A Literature Review of Academic Performance, an Insight into Factors and their Influences on Academic Outcomes of Students at Senior High Schools
}

\author{
Evans Austin Brew ${ }^{1 *}$, Benjamin Nketiah ${ }^{2}$, Richard Koranteng ${ }^{3}$ \\ ${ }^{1}$ Department of Basic Education, University of Cape Coast, Cape Coast, Ghana \\ ${ }^{2}$ Library Department, Akenten Appiah-Menka University of Skills Training and Entrepreneurial Development (AAMUSTED), \\ Asante Mampong Campus, Ghana \\ ${ }^{3}$ Department of Biological Sciences Education, Akenten Appiah-Menka University of Skills Training and Entrepreneurial Development \\ (AAMUSTED), Asante Mampong Campus, Ghana \\ Email: *austinbrew22@gmail.com
}

How to cite this paper: Brew, E.A., Nketiah, B. and Koranteng, R. (2021) A Literature Review of Academic Performance, an Insight into Factors and their Influences on Academic Outcomes of Students at Senior High Schools. Open Access Library Journal, 8: e7423.

https://doi.org/10.4236/oalib.1107423

Received: April 14, 2021

Accepted: May 30, 2021

Published: June 2, 2021

Copyright $\odot 2021$ by author(s) and Open Access Library Inc.

This work is licensed under the Creative Commons Attribution International License (CC BY 4.0).

http://creativecommons.org/licenses/by/4.0/

\begin{abstract}
The good academic performance of students at the Senior High School is of paramount importance in every educational system. Meanwhile, numerous factors influence the academic performance of students and have been researched, but many problems persist. A literature review in this area would provide the gaps and areas that need more research and will go a long way to curb the situation. The current paper used a narrative review method to review the literature on the academic performance of students at Senior High Schools and various factors affecting students' performance. The paper elucidated how these factors negatively affect academic performance and the need for them to be minimized to improve students' academic performance. The study found out that, truancy affects academic performance drastically and sometimes even leads to school dropout. Also, the study found out that other factors such as students' parental levels of education and income, textbooks availability and accessibility, libraries, practical laboratory, meals provision and teachers have tremendous effects on the academic performance of students at school. Students who are above average academically and are positively exposed to these factors are likely to perform better as compared to those who are less exposed to these factors. The study recommends that factors such as truancy, parental levels of education and income, textbooks availability and accessibility, libraries, practical laboratory, meals provision and teachers should be regularly monitored and adjusted to meet students'
\end{abstract}


needs and aspirations. This will go a long way to improve the academic performance of students and hence allow them to achieve their aims in life.

\section{Subject Areas}

Education

\section{Keywords}

Academic Performance, Factors, Parents, Teachers

\section{Introduction}

It is highly significant to note that a human being's entire existence is commonly based on the amount of knowledge he or she acquires, how much this knowledge is utilized in developing himself, his country, and the world at large. This explains the reason underlying the need for education. The basic thing that one gets from education is knowledge. One gets to know about various things ranging from Mathematics to History, Literature to Political Science [1]. The worldly knowledge we gain from education plays a great role in our future life and helps us to understand the happenings in a much more cohesive manner. Meanwhile, educational success is a measure based on the academic performance of students.

Educators and researchers have long been interested in exploring variables contributing to the quality of academic performance of learners. Academic performance is affected by many factors including parents' education levels and income, teachers' knowledge of the subject, truancy, textbooks availability and accessibility, libraries, practical laboratory, meals provision and many other factors [2]. The home environment has been recognized as having a lot of influence on academic performance. Children who experience poverty may live in physical environments that offer less stimulation and fewer resources for learning. Education at the secondary school level is supposed to be the bedrock and the foundation towards higher knowledge in tertiary institutions [3]. Consistent lower academic performance at the Senior High School is a threat to every country's educational system, especially Ghana. There is therefore the need to review the literature on academic performance, and insight into factors and their influences on academic outcomes of students at Senior High Schools. This is one way or the other could help expose some gaps in the literature and other issues that have been favoured by research and publications. This study has been structured to review literature on factors and their influences on academic outcomes of students at senior high schools.

\section{Methods}

The study used a narrative review method to find out how the academic performance of students is affected by their needs in the school. To achieve this, the 
researchers employed search styles and methods from previous studies [4] [5] with few modifications. The modifications included the search terms (academic performance, teachers and academic performance, students and academic performance, hunger and academic performance etc.) and phrases since the study papers are of different topics and scope and hence the modification. Search terms employed in the current study included but not limited to academic performance, Senior High School student's performance, students attendance to the library, the importance of meals in academic performance, truancy and academic performance, parents' income and academic performance, textbooks and academic performance, etc.

\section{Organization of the Study}

The literature review is of paramount importance to update the current information and trend of research on factors that influence the academic performance of students at the senior high school level. This is hoped to provide the gaps and areas that need to be researched for the betterment of educational systems. To achieve this, the study was organized into an introduction, methods and other topics including, the influence of truancy on academic performance in secondary schools, the influence of parents' levels of education on students' academic performance, the influence of parents' income on academic performance of students in secondary schools, the influence of textbooks on academic achievement, the influence of libraries on academic achievement, laboratory and academic achievement, meals provision at school and academic performance in secondary schools, the influence of teachers on students' academic performance, conclusion and recommendations.

\subsection{Influence of Truancy on Academic Performance in Secondary Schools}

The act of being absent from school above the allowable period without permission is termed as obstinate truancy [6]. Though truancy is a major challenge that is recognized in various parts of the country, the difficulty of collecting and presenting data at various stages (school, local and states) have led to the lack of data that fully presents a clear picture of the situation [7].

Being truant can usually begin at the initial stage of schooling of which the resultant effect will be both short and long term low-grade academic performance [8]. Among students specifically of Latin American descent, continuous absenteeism affects their academic output even at the early stage of their first grade [9]. Unfortunately, a larger number of these truant students are not able to catch up with the missed classes as a result of the poor financial background [10]. Hence the appearance of these trends affects the lives of the students and the community they belong to in the long run [11].

It was worthy to note that, truancy is not only detrimental to the individual and his/her vision but affects other students by way of impeding the progress of 
teaching and causing damage to the overall performance of the school [12]. Conversely, truancy amongst teachers also messes up the academic output of students. This is confirmed by a report which indicated that the academic achievement of students is adversely impacted to a larger extent when teachers are truant [13]. This situation worsens by additionally declining the scores of the students on standardized tests when they are absent from the class in more days. However, a lot of teachers who usually absent themselves from school either request a leave from school leaders or they are sick [14].

\subsection{Influence of Parents' Levels of Education on Student Academic Performance}

One other factor that has the propensity to influence the academic output of the student is the natural surroundings he/she belongs to. However, such surroundings that could soothe the performance of the student can be given by the parents [15]. Parents can also benefit from sessions of guidance and counselling from school leaders to help enhance the academic work of students at home [16]. For students to achieve a higher degree of academic excellence, several researchers have posited that students reaching this fate mainly rely on the academic influence of their parents [17]. As a result, [18] in their work inferred that the mark of students from literate parents exceeds those from illiterate parents on a standardized exam. This is because literate parents can share information with their children concerning school [10] and what is being studied. Additionally, they are capable of helping their wards in their academic work and their involvement in school activities [19].

Therefore, the education of parents is significant in anticipating the performance of students and this has been frequently pointed out in several types of research reporting on students' performance [20]. Among the parents, mother's higher education reflected in the performance of students in Mathematics and Reading due to their increased hopes from their wards [21]. He further asserted that a higher level of performance-associated conduct by mothers in the house and a more definite insight of performance by the children was projected by more definite confidence and hopes from mothers [21].

\subsection{Influence of Parents' Income on Academic Performance of Students in Secondary Schools}

A study that compared families of low- and high-income earners indicated that parents who are average to extreme income earners that is consistent with their educational level cleave to similar views and visions as compared to families earning smaller wages and their views about the educational achievements of their wards [22]. However, there was no relationship between the higher hopes and achievement visions families from poor financial background conceived about their wards and their real academic achievements [23].

A study indicated that students from poor family backgrounds are put under slavery work and have limited time to study and this happens because they es- 
teem household work more than education. Also, prevalent in developing nations are several families who are not capable of feeding twice daily despite working throughout the day [24]. Hence, children of the young age of such households engage in menial jobs to survive. However, the little money gained together with the scanty financial provision by the government in education causes these poor families the inability to fund their wards education resulting in low academic achievements [25].

\subsection{Influence of Textbooks on Academic Achievement}

The textbook is an instructional material that also determines the success of a student. This has been confirmed by several studies which have indicated the role textbooks play in a student's academic performance [26]. Then also textbooks serve as the only material from which information for the student and program of study are gathered [27]. A study investigated the impact of textbooks and other factors on students' performance when data was collected from eight-grade Mathematics classes across the country in Thailand. It was observed that textbooks influenced performance by presenting a complete and well-detailed curriculum as well as replacing subsequent mathematics education after secondary school [28]. Moreover, according to [29], textbooks are principal at every stage of a school because nothing has substituted books as a vital part of the educational process.

Teachers striving for the enhancement of students education esteem that, enhancing teaching books would certainly result in the alteration of instruction [30] and another author asserted about teachers dependence on textbooks [31]. Several teachers assume that textbooks could offer significant and efficient information without taking into consideration the role of instructors [32]. Textbooks have been emphasized as so essential to academic improvement that, [33] posited that unavailability of significant textbooks for instruction and studies is an unfortunate incidence [34]. Then also, students not able to buy textbooks are one of the factors accounting for their unavailability among students [35]. In this way, it would only be from teachers that students will get access to information and in this situation, a teacher's choice of textbooks will be partial [36]. Partial because, it will rely on sensibly deficient standards such as the appealing nature of books taking into consideration the print, pictures as well as the credentials and acknowledgement the writer has received in his or her other writings [36]. Research by [37] which showed the relationship between resource and resource exploitation and academic performance further explained that there existed a high association between suggested textbooks and academic output in Integrated Science [37].

\subsection{Influence of Libraries on Academic Achievement}

The storage place or apartment for a compendium of reports, books, recordings, research articles and journals for reading, learning, and lending is termed as a 
library [38]. A library remains one of the significant elements in instruction and knowledge acquisition as such forms one of the key provisions of the educational system. Then also the earth's pool of books facilitates the role of the educational process [39]. To make available to students textbooks of concern, worth and those that are not their main or additional material, the library functions to provide an avenue for students to get access to these books, periodicals and other printed books at ease [40].

In the school system, a library as an asset is cardinal and occupies a fundamental position. Therefore, it assists the role of instruction and presents direction as well as aid to its users [41]. According to [42], a library must have two most important things: it must be current and historic (contains past books). Then also, libraries must be funded to enable book acquisition coupled with the provision of other responsibilities [43]. He finally inferred that a properly furnished library is a substantial complex that facilitates positive students and their attainment of maximum educational level. Another researcher, [44], indicated that, if material found within the library is few and not current, the library is not productive. And when it is continuously locked during a specified period of school hours, then the significance of the library will not be realistic. However, despite the earlier indicated realities, it is sorrowful that several schools run without a library [45]. The unavailability of a defined school library would continuously be severely fatal to a lot of secondary school students [46]. This means that several schools operating without a library resulted in a decline in the academic achievements of students. Additionally, the school library has been pointed out by [47] as a significant teaching asset that affects students' performance after regulating for students' family background. He further observed that a single consequence of library capacity and services have been observed in 15 out of 18 investigations. Wherein school provided with a well-furnished library performed better. [48] also stated that a group of materials stored in the library for studying was associated with academic performance, which he asserted in research about elevating the efficiency of schools in developing nations [49].

\subsection{Laboratory and Academic Achievement}

To practicalize theories by illustration during instructional periods takes place in an area known as a laboratory which has been purposely instituted for that said action [50]. The importance of a laboratory has been emphasized during the instruction of science in that, students tend to understand and recollect more when they are made to have a feel than just listening [51]. Hence, the efficiency of any science subject is contingent on a laboratory at its dispense. Therefore, the laboratory is an epicentre during the teaching of science [52].

In any hands-on studying process, students are made to partake in exercises such as observation, enumeration, trials, quantifying, recording and undertaking duties outside class [53]. However, these field exercises are highly distinct from taught theories which are characterized by hearkening to presentations and re- 
cording what is presented [54]. As students are made to partake in significant exercises and testings in the laboratory, their passions are aroused [55]. Science is not only about yield or procedures but laboratory duties equip students with fundamental proficiencies and knowledge of dealing with situations using the scientific procedure [56].

The laboratory serves as the medium through which students have the opportunity to transform their convictions, thoughts, assertions and hypothetical suggestions into the trial [57]. The teacher also on the other hand has a role of partaking in laboratory activities to ensure the transfer of information and truths to students. This is bid helps to sustain and stimulate the curiosities of students in studies containing laboratory work for higher academic output [58]. Consistent with this, one lingers to probe that at what length have the laboratory been able to attain its purpose? Comparing the role of teachers and the laboratory a study emphasized that, the teacher acts as a distributor of knowledge whereas the laboratory plays the role of practice or confirmation [59]. Additionally, they expounded at another end, the duty of a teacher which is to provide direction to students and the laboratory serving as an avenue to unearth information [60].

In contrast, rising proofs suggest that teachers do not display actions that correspond to attaining the specified goals. Some consist of the way of instructing practical subjects; insufficient or lack of well-furnished laboratories; increased number of learners; lack of infrastructure for instructing and studying hands-on subjects as well the number and excellence of teachers [61]. [62] also found an overall shortfall of assets in some recently built secondary schools in Lagos during its study of assets for instructing and studying Biology. He further discovered amidst other factors that, the majority $(80 \%)$ of schools that indicated the presence of laboratories, contained a well-stocked laboratory. Second, a smaller percentage (40\%) of the schools was found to have no laboratories whereas the remainder $(60 \%)$ had an area apportioned as a laboratory but without sufficient instruments. She then inferred that learners studying skills would be restrained due to the complication involved in instructing Biology practicals [62].

Another author also acknowledged in his research that, when there is a lack of instruments for instruction, no science education course can survive [63]. Rose highlighted that the conditions in second cycle schools recently indicated that laboratory racks have become full of bottles devoid of chemicals [64]. However, the academic performance of schools with a well-stocked laboratory has been revealed to highly exceed those without, in the final science certificate examinations [65]. In agreement with the previous statement, the marks obtained by learners taught solely by laboratory procedures in attitude were higher but with a drop in performance marks as compared to those taught solely by the indigenous lecture method [66].

[67] asserted that the non-existence of practical in any Science and Mathematics programs makes it incomplete. The practical duty must be undertaken by students either in the science laboratory or in the classroom. Since we study by 
practice, it very important to undertake practical work especially at the school stage, therefore, making scientific drills and their usage be accordingly presented consequentially. It is a fact that, an item held by hand imprints on the mind strongly as compared to items only viewed afar or during a presentation [68].

\subsection{Meals Provision at School and Academic Performance in Secondary Schools}

Food is an essential component of education and it is vital to the well being of humans, especially students. Thus, for students to get along with class duties, concentrate and learn thoroughly, energy from food is required to facilitate these actions [69]. Studies have found out that, students who do not partake in breakfast are usually affected in their ability to deal with some critical subjects like Mathematics which utilises analytical skills [70].

\subsection{Influence of Teachers on Students' Academic Performance}

One other factor that accounts for the low academic performance of students is the number of teachers which are proportionally smaller than the students [71]. Despite the smaller number of these teachers in the public schools, they additionally engage in other menial jobs or hold personal ventures to help them make a living and this is due to the inadequate salary paid by the government [72]. These unsatisfactory conditions of service have led to an increased level of truancy, the lessened edge for work, declined efficacy in class, lower motivation and work fulfilment in schools [73]. However, zeal, increased motivation, collaboration and receipt of duties exist where the conditions of service are of high value. Therefore, the above consequences of ineffectiveness on the part of teachers depict how they affect students' education [74].

Moreover for education to fully achieve its purpose, teachers play a key function by way of interpreting, displaying and setting standards following educational programs during school hours [75]. Hence, teachers determine how teaching and learning occurs. [76] therefore, hypothesized that a teacher is characterized as being productive when he/she brings out the required outcome when performing his/her role as a teacher.

\section{Conclusion}

The study was designed to review the literature on the influences of various needs of students on their academic performance. The study revealed that truancy affects academic performance drastically and sometimes even leads to school dropout. Also, the study finds out that other factors such as students' parents' levels of education and income, textbooks availability and accessibility, libraries, practical laboratory, meals provision and teachers have tremendous effects on the academic performance of students at school. Students who are above average academically, positively exposed to these factors are likely to perform better as compared to those who are less exposed to these factors. 


\section{Recommendations}

The study recommends that factors such as truancy, parents' levels of education and income, textbooks availability and accessibility, libraries, practical laboratory, meals provision and teachers should be regularly monitored and adjusted to meet students' needs and aspirations. Specifically, truancy negatively affects academic performance and should be eradicated. Also, most parents should be educated on the importance of educating their wards. Policymakers or funding should be invested in implementation research since some of these are available yet the intended coverage is not achieved. This will go a long way to improve the academic performance of students and hence allow them to achieve their aims in life.

\section{Limitations}

The study was limited in that, it did was a narrative review by not a systematic one and hence various events were not presented in a chronological other.

\section{Acknowledgements}

We wish to acknowledge the efforts of Mr. Gadafi Iddrisu Balali of the Department of Theoretical and Applied Biology, Kwame Nkrumah University of Science and Technology, Kumasi, Ghana and who also doubled as the CEO of MicoTech Research Group for his intellectual guidance. We also wish to acknowledge Dr. George Oduro Okyireh of the Department of Interdisciplinary Studies, Akenten Appiah-Menka University of Skills Training and Entrepreneurial Development (AAMUSTED), Mampong Campus, Ashanti, Ghana for his time and assistance in expurgation of the manuscript.

\section{Funding}

This was funded by the authors.

\section{Availability of Supporting Data}

All data used for this manuscript are available upon a reasonable request.

\section{Contributions}

$\mathrm{AB}$ conceptualized the study. All authors contributed equally in the drafting, editing and finally reviewing the manuscript for publication.

\section{Consent for Publication}

We have all read the final manuscript and consented to it for publication.

\section{Conflicts of Interest}

The authors declare no conflicts of interest regarding the publication of this paper. 


\section{References}

[1] Bruner, J.S. (2009) The Process of Education. Harvard University Press, Cambridge.

[2] Chinyoka, K. and Naidu, N. (2013) Uncaging the Caged: Exploring the Impact of Poverty on the Academic Performance of Form Three Learners in Zimbabwe. International Journal of Educational Sciences, 5, 271-281. https://doi.org/10.1080/09751122.2013.11890087

[3] Chindanya, A. (2012) Effects of Parental Involvement in the Education of Children. Unpublished D. Ed. Thesis, University of South Africa, Pretoria.

[4] Mustapha, H.S. and Benjamin, N. (2021) Ethics: An Insight into Psychological Research and Practice. Open Access Library Journal, 8, e7110.

https://doi.org/10.4236/oalib.1107110

[5] Balali, G.I., Yar, D.D., Dela, V.G.A. and Adjei-Kusi, P. (2020) Microbial Contamination, an Increasing Threat to the Consumption of Fresh Fruits and Vegetables in Today's World. International Journal of Microbiology, 2020, Article ID: 3029295. https://doi.org/10.1155/2020/3029295

[6] Baskerville, D.J. (2020) Mattering; Changing the Narrative in Secondary Schools for Youth Who Truant. Journal of Youth Studies, 23, 1-16. https://doi.org/10.1080/13676261.2020.1772962

[7] Maynard, B.R., McCrea, K.T., Pigott, T.D. and Kelly, M.S. (2012) Indicated Truancy Interventions: Effects on School Attendance among Chronic Truant Students. Campbell Systematic Reviews, 8, 1-84. https://doi.org/10.4073/csr.2012.10

[8] Mchelu, A. (2015) The Effect of Long Commuting on Students' Academic Performance in Day Community Secondary Schools in Tanzania: A Case of Songea Municipal Council. The Open University of Tanzania, Dar es Salaam.

[9] Jackson, M., Jonsson, J.O. and Rudolphi, F.J. (2012) Ethnic Inequality in Choice-Driven Education Systems: A Longitudinal Study of Performance and Choice in England and Sweden. Sociology of Education, 85, 158-178.

https://doi.org/10.1177\%2F0038040711427311

[10] Mallett, C.A. (2016) Truancy: It's Not about Skipping School. Child and Adolescent Social Work Journal, 33, 337-347. https://doi.org/10.1007/s10560-015-0433-1

[11] Romero, D. and Molina, A. (2011) Collaborative Networked Organisations and Customer Communities: Value Co-Creation and Co-Innovation in the Networking Era. Production Planning \& Control, 22, 447-472. https://doi.org/10.1080/09537287.2010.536619

[12] Keppens, G. and Spruyt, B. (2017) The Development of Persistent Truant Behaviour: An Exploratory Analysis of Adolescents' Perspectives. Educational Research, 59, 353-370. https://doi.org/10.1080/00131881.2017.1339286

[13] Onyele, C.V. (2018) Influence of Truancy on Academic Performance of Secondary School Students in Enugu East Local Government Area of Enugu Stste.

[14] Gottfried, M.A. (2019) Chronic Absenteeism in the Classroom Context: Effects on Achievement. Urban Education, 54, 3-34. https://doi.org/10.1177\%2F0042085915618709

[15] Roman, M.D. (2014) Students' Failure in Academic Environment. Procedia-Social and Behavioral Sciences, 114, 170-177. https://doi.org/10.1016/j.sbspro.2013.12.679

[16] Walker, J.M., Shenker, S.S. and Hoover-Dempsey, K.V. (2010) Why Do Parents Become Involved in Their Children's Education? Implications for School Counselors. Professional School Counseling, 14, 2156759X1001400104. https://doi.org/10.1177\%2F2156759X1001400104 
[17] Shifrer, D. (2013) Stigma of a Label: Educational Expectations for High School Students Labeled with Learning Disabilities. Journal of Health and Social Behavior, 54, 462-480. https://doi.org/10.1177\%2F0022146513503346

[18] Akben-Selcuk, E. and Altiok-Yilmaz, A. (2014) Financial Literacy among Turkish College Students: The Role of Formal Education, Learning Approaches, and Parental Teaching. Psychological Reports, 115, 351-371. https://doi.org/10.2466\%2F31.11.PR0.115c18z3

[19] Thompson, L.J., Clark, G., Walker, M. and Duncan Whyatt, J. (2013) 'It's Just Like an Extra String to Your Bow': Exploring Higher Education Students' Perceptions and Experiences of Extracurricular Activity and Employability. Active Learning in Higher Education, 14, 135-147. https://doi.org/10.1177\%2F1469787413481129

[20] Park, H., Byun, S.-Y., and Kim, K.-K. (2011) Parental Involvement and Students' Cognitive Outcomes in Korea: Focusing on Private Tutoring. Sociology of Education, 84, 3-22. https://doi.org/10.1177\%2F0038040710392719

[21] Boi, B.L. (2020) The Influence of Home Environment on Learning Achievements among Students' in Public Day Secondary Schools in Mbulu Town Council-Tanzania. The University of Dodoma, Dodoma.

[22] Watt, H.M. (2010) Gender and Occupational Choice. In: Chrisler, J. and McCreary, D., Ed., Handbook of Gender Research in Psychology, Springer, New York, 379-400. https://doi.org/10.1007/978-1-4419-1467-5_16

[23] Noguera, P.A. and Wells, L.J. (2011) The Politics of School Reform: A Broader and Bolder Approach for Newark. Berkeley Review of Education, 2, 1-25.

[24] Corak, M.J. (2013) Income Inequality, Equality of Opportunity, and Intergenerational Mobility. Journal of Economic Perspectives, 27, 79-102. https://doi.org/10.1257/jep.27.3.79

[25] Mauka, A.M. (2015) Parental Involvement and Its Effects on Students' Academic Performance in Public Secondary Schools in Korogwe, Tanzania. The Open University of Tanzania, Dar es Salaam.

[26] Abdulghani, H.M., Al-Drees, A.A., Khalil, M.S., Ahmad, F., Ponnamperuma, G.G. and Amin, Z. (2014) What Factors Determine Academic Achievement in High Achieving Undergraduate Medical Students? A Qualitative Study. Medical Teacher, 36, S43-S48. https://doi.org/10.3109/0142159X.2014.886011

[27] Junco, R. and Clem, C. (2015) Predicting Course Outcomes with Digital Textbook Usage Data. The Internet and Higher Education, 27, 54-63.

https://doi.org/10.1016/j.iheduc.2015.06.001

[28] Fan, L., Zhu, Y. and Miao, Z.J.Z. (2013) Textbook Research in Mathematics Education: Development Status and Directions. ZDM, 45, 633-646. https://doi.org/10.1007/s11858-013-0539-x

[29] Owoeye, J.S. and Olatunde Yara, P.J. (2011) School Facilities and Academic Achievement of Secondary School Agricultural Science in Ekiti State, Nigeria. Asian Social Science, 7, 64-74. https://doi.org/10.5539/ass.v7n7p64

[30] Pelton, R.P. (2010) Action Research for Teacher Candidates: Using Classroom Data to Enhance Instruction. R\&L Education, Melbourne.

[31] Hord, S.M. and Tobia, E.F. (2015) Reclaiming Our Teaching Profession: The Power of Educators Learning in Community. Teachers College Press, New York.

[32] Muijs, D. and Reynolds, D. (2017) Effective Teaching: Evidence and Practice. Sage, Newbury Park.

[33] O’Leary, E.S., Shapiro, C., Toma, S., Sayson, H.W., Levis-Fitzgerald, M. and John- 
son, T. (2020) Creating Inclusive Classrooms by Engaging STEM Faculty in Culturally Responsive Teaching Workshops. International Journal of STEM Education, 7, Article No. 32. https://doi.org/10.1186/s40594-020-00230-7

[34] Adu, K. (2018) The Use of Textbooks by Teachers in Teaching Mathematics at Selected Primary Schools in East London Education District. University of Fort Hare, Alice.

[35] Sun, J., Flores, J. and Tanguma, J. (2012) E-Textbooks and Students' Learning Experiences. Decision Sciences Journal of Innovative Education, 10, 63-77. https://doi.org/10.1111/j.1540-4609.2011.00329.x

[36] Loewen, J.W. (2018) Teaching What Really Happened: How to Avoid the Tyranny of Textbooks and Get Students Excited about Doing History. Teachers College Press, New York.

[37] Collins, A. and Halverson, R. (2018) Rethinking Education in the Age of Technology: The Digital Revolution and Schooling in America. Teachers College Press, New York.

[38] Read, T. (2015) Where Have All the Textbooks Gone? Toward Sustainable Provision of Teaching and Learning Materials in Sub-Saharan Africa. The World Bank, Washington DC. https://doi.org/10.1596/978-1-4648-0572-1

[39] Hansen, E.J. (2012) Idea-Based Learning: A Course Design Process to Promote Conceptual Understanding. Stylus Publishing, LLC., Sterling.

[40] De Oliveira, S.M. (2012) E-Textbooks Usage by Students at Andrews University: A Study of Attitudes, Perceptions, and Behaviors. 33rd Annual IATUL Conference, 4-7 June 2012, Paper No. 32.

[41] Bishop, K. (2012) The Collection Program in Schools: Concepts and Practices. Libraries Unlimited, Inc., Santa Barbara.

[42] Gbemi-Ogunleye, P. (2016) Library Use and Students Academic Achievement: Implication for Counseling. Information and Knowledge Management, 6, 50-52.

[43] Rubin, R.E. (2017) Foundations of Library and Information Science. American Library Association, Chicago.

[44] Heok, A.K.H. and Luyt, B. (2010) Imagining the Internet: Learning and Access to Information in Singapore's Public Libraries. Journal of Documentation, 66, 475-490. https://doi.org/10.1108/00220411011052911

[45] Bangs, J., MacBeath, J. and Galton, M. (2010) Reinventing Schools, Reforming Teaching: From Political Visions to Classroom Reality. Routledge, London. https://doi.org/10.4324/9780203840344

[46] Stephens, C.G. and Franklin, P. (2012) School Library Collection Development: Just the Basics. ABC-CLIO, Santa Barbara.

[47] Muendo, J.K. (2016) Influence of School Infrastructural Environment on Performance in Kenya Certificate of Secondary Education in Kibauni Division of Machakos Count, Kenya. University of Nairobi, Nairobi.

[48] Rasheed, S.T. and Shoaga, O. (2019) The Influence of Home Violence on Psychosocial Adjustment of Junior Secondary School Pupils in Ijebu North Local Government, Ogun State Nigeria. KIU Journal of Humanities, 4, 135-139.

[49] Shoaga, O. and Rasheed, S. (2019) Homework Type, Parental Occupational Status and Academic Performance of Primary School Pupils in English and Mathematics in Ijebu North Local Government, Ogun State, Nigeria. KIU Journal of Social Sciences, 5, 157-162.

[50] Ali, M. (2013) The Effect of the Project Method on the Development of Creative 
Thinking, Critical Thinking and Emotional Intelligence: A Case Study of Secondary School Students in the State of Kuwait. University of Zurich, Zürich.

[51] Toplis, R.J. (2012) Students' Views about Secondary School Science Lessons: The Role of Practical Work. Research in Science Education, 42, 531-549. https://doi.org/10.1007/s11165-011-9209-6

[52] Roth, W.-M. (2012) Authentic School Science: Knowing and Learning in Open-Inquiry Science Laboratories. Vol. 1., Springer Science \& Business Media, Dordrecht. https://doi.org/10.1007/978-94-011-0495-1

[53] Mandinach, E.B. and Cline, H.F. (2013) Classroom Dynamics: Implementing a Technology-Based Learning Environment. Routledge, New York. https://doi.org/10.4324/9781315044446

[54] Mhlolo, M.K. (2011) From Coherence in Theory to Coherence in Practice: A Stock-Take of the Written, Tested and Taught National Curriculum Statement for Mathematics (NCSM) at further education and training (FET) level in South Africa. University of the Witwatersrand, Johannesburg, South Africa.

http://wiredspace.wits.ac.za/bitstream/handle/10539/11274/Mhlolo\%20M\%20K\%20 PhD\%20Final\%20Thesis.pdf

[55] Watters, J. (2021) Why Is It So? Interest and Curiosity in Supporting Students Gifted in Science. In: Smith, S.R., Ed., Handbook of Giftedness and Talent Development in the Asia-Pacific, Springe, Singapore, 761-786. https://doi.org/10.1007/978-981-13-3041-4_34

[56] Allchin, D.J. (2011) Evaluating Knowledge of the Nature of (Whole) Science. Science Education, 95, 518-542. https://doi.org/10.1002/sce.20432

[57] Medawar, P.B. (2013) Induction and Intuition in Scientific Thought. Routledge, London. https://doi.org/10.4324/9780203706299

[58] Gregory, G. and Kaufeldt, M. (2015) The Motivated Brain: Improving Student Attention, Engagement, and Perseverance. Association for Supervision and Curriculum Development, Alexandria.

[59] Nivalainen, V., Asikainen, M.A. and Hirvonen, P.E. (2013) Open Guided Inquiry Laboratory in Physics Teacher Education. Journal of Science Teacher Education, 24, 449-474. https://doi.org/10.1007/s10972-012-9316-x

[60] Peters, R.S. (2010) The Concept of Education (International Library of the Philosophy of Education Volume 17). Vol. 17, Routledge, London. https://doi.org/10.4324/9780203861073

[61] Mulela, M.M. (2015) Effects of Availability and Use of Laboratories on Students Performance in Science Subjects in Community Secondary Schools. The Open University of Tanzania, Dar es Salaam.

[62] Owiti, A.E. (2017) Teacher Practices that Hamper Effective Integration of Information Communication and Technology in Biology Instruction in Secondary Schools in Migori County, Kenya.

[63] Braaten, M. and Windschitl, M. (2011) Working toward a Stronger Conceptualization of Scientific Explanation for Science Education. Science Education, 95, 639-669. https://doi.org/10.1002/sce.20449

[64] Rose, M. (2014) Why School? Reclaiming Education for All of Us. The New Press, New York.

[65] Mersha, Y., Bishaw, A. and Tegegne, F. (2013) Factors Affecting Female Students' Academic Achievement at Bahir Dar University. Journal of International Cooperation in Education, 15, 135-148.

[66] Groen, J.F., Quigley, B. and Herry, Y. (2016) Examining the Use of Lecture Capture 
Technology: Implications for Teaching and Learning. The Canadian Journal for the Scholarship of Teaching and Learning, 7, Article No. 8.

[67] Ilomo, O. and Mlavi, B. (2016) The Availability of Teaching and Learning Facilities and Their Effects on Academic Performance in Ward Secondary Schools in Muheza-Tanzania. International Journal of Education and Research, 4, 571-581.

[68] Isozaki, T. (2017) Laboratory Work as a Teaching Method: A Historical Case Study of the Institutionalization of Laboratory Science in Japan. Espacio, Tiempo y Educación, 4, 101-120. https://doi.org/10.14516/ete.177

[69] Kahu, E. (2013) Framing Student Engagement in Higher Education. Studies in Higher Education, 38, 758-773. https://doi.org/10.1080/03075079.2011.598505

[70] Adolphus, K., Lawton, C.L. and Dye, L. (2013) The Effects of Breakfast on Behavior and Academic Performance in Children and Adolescents. Frontiers in Human Neuroscience, 7, Article No. 425. https://doi.org/10.3389/fnhum.2013.00425

[71] Riegle-Crumb, C. (2010) More Girls Go to College: Exploring the Social and Academic Factors behind the Female Postsecondary Advantage among Hispanic and White Students. Research in Higher Education, 51, 573-593.

https://doi.org/10.1007/s11162-010-9169-0

[72] Nilson, L.B. (2016) Teaching at Its Best: A Research-Based Resource for College Instructors. John Wiley \& Sons, Hoboken.

[73] Reynolds, D. (2010) Failure-Free Education? The Past, Present and Future of School Effectiveness and School Improvement. Routledge, London.

[74] Seniwoliba, J. (2013) Teacher Motivation and Job Satisfaction in Senior High Schools in the Tamale Metropolis of Ghana. Merit Research Journal of Education and Review, 1, 181-196.

[75] Brown, J.C. (2017) A Metasynthesis of the Complementarity of Culturally Responsive and Inquiry-Based Science Education in K-12 Settings: Implications for Advancing Equitable Science Teaching and Learning. Journal of Research in Science Teaching, 54, 1143-1173. https://doi.org/10.1002/tea.21401

[76] Brookfield, S.D. (2017) Becoming a Critically Reflective Teacher. John Wiley \& Sons, Hobken. 